\title{
Phosphorus dynamics in a subtropical coastal lake in Southern Brazil
}

\author{
Aurea L. Lemes da Silva, ${ }^{1 *}$ Mariana C. Hennemann, ${ }^{2}$ Mauricio M. Petrucio ${ }^{2}$ \\ ${ }^{1}$ Programa de Pós-Graduação em Ecologia, Departamento de Ecologia e Zoologia, Centro de Ciências Biológicas, Universidade \\ Federal de Santa Catarina, Campus Universitário s/n, Trindade, Florianópolis, Santa Catarina; ${ }^{2}$ Laboratório de Ecologia de Águas \\ Continentais, Departamento de Ecologia e Zoologia, Centro de Ciências Biológicas, Universidade Federal de Santa Catarina, \\ Campus Universitário s/n, Trindade, Florianópolis, Santa Catarina, Brazil
}

\begin{abstract}
Temporal and spatial variations of organic and inorganic forms of phosphorus in the sediments of a subtropical oligo-mesotrophic shallow lake were investigated in relation to water column parameters, sediment characteristics and benthic fauna. The main results found were: i) Phosphorus (P) concentration varied seasonally, with organic P and total P increasing in the sediments in warmer periods; i) Sediment spatial variation, in terms of grain size composition and organic matter content, influenced P concentrations; iii) quantities and qualities of $\mathrm{P}$ in the sediments were positively correlated with water parameters, especially $\mathrm{DO}$ and $\mathrm{NO}_{3}, \mathrm{Chl}-\mathrm{a}$, water temperature, $\mathrm{pH}$, and total $\mathrm{P}$. Negative correlations were observed between \%OP and $\mathrm{DO}$ in sites 1,3 and 4 , and with $\mathrm{NO}_{3}$ in sites 2, 3 and 4 ; iv) benthic functional feeding groups showed significant relationships with temporal variation in sediment $\mathrm{P}$ concentration, including gathering-collectors, shredders, filterers and filtering-collectors. The results suggest a high importance of temperature mediated control of sediment-P release, both directly, through its direct effects on primary production and decomposition rates, and indirectly through its effects on other water and sediment parameters, especially dissolved oxygen concentration.
\end{abstract}

\section{INTRODUCTION}

It is well know that growth and reproduction of photosynthetic biota (autotrophs hereafter) as well as large scale ecosystem primary production are frequently limited by supplies of nitrogen $(\mathrm{N})$ or phosphorus $(\mathrm{P})$ in freshwater environments (Elser et al., 2011; Hou et al., 2012). However, $\mathrm{P}$ is has been recognized as the most critical nutrient limiting lake productivity (Chapra et al., 2012). P sources in a lake can be external (allochthonous), comprising point (e.g., industrial and municipal effluents) and non-point sources (e.g., rainfall, runoff, soil leaching), and internal (autochthonous) from the system itself, such as aquatic plants, phytoplankton, bacteria and sediments (Kaiserli et al., 2002; Torres et al., 2014). Especially in shallow lakes, sediments play an important role in P cycling,

Corresponding author: aurealuizalemes@gmail.com

Key words: Phosphorus release; subtropical lake; sediment phosphorus; macroinvertebrates; Southern Brazil.

Edited by: Michela Rogora, CNR-IRSA Verbania, Italy.

Received: 6 February 2019

Accepted: 3 August 2019.

This work is licensed under a Creative Commons Attribution NonCommercial 4.0 License (CC BY-NC 4.0).

${ }^{\circ}$ Copyright: the Author(s), 2019

Licensee PAGEPress, Italy

J. Limnol., 2020; 79(1): 1-12

DOI: 10.4081/jlimnol.2019.1894 acting as both a sink and a source of $\mathrm{P}$, due to the high ratio of sediment surface to water column (Søndergaard et al., 2001; Dong et al., 2011; Zhang et al., 2014). P flux from sediments can be an important factor in the regulation of the trophic state of aquatic systems, especially in shallow waters (Kinsman-Costello et al., 2016).

The factors governing P release from sediments are numerous and include the redox reactions, adsorption, mineral phase solubility and mineralization of organic matter (Gächter and Meyer, 1993; Lijklema, 1993). The environmental variables that appear to regulate the release rate of dissolved $\mathrm{P}$ from sediments are dissolved oxygen (DO), nitrates, $\mathrm{pH}$ (by affecting the strength of ionic phosphate sorption to sediment solid surfaces) and temperature, as demonstrated by a number of studies (Andersen and Jensen ,1992; Kleeberg and Dudel ,1997; Katsev et al., 2006, Spears et al., 2006; Anthony and Lewis, 2012; Wu et al., 2014). The classical model for $\mathrm{P}$ fluxes between sediments and water of Mortimer (1941) links sediment $\mathrm{P}$ efflux to redox conditions at the sediment-water interface that are effectively controlled by DO concentration in bottom water. According to the model, when the sediment surface is oxic, dissolved phosphate is strongly adsorbed to iron oxyhydroxides, what limits the $\mathrm{P}$ efflux by preventing phosphate diffusion into the water column from deeper reduced sediments. When anoxic conditions occur in the sediment surfaces, iron oxyhydroxides are reduced and phosphate can be released into the water column. However, numerous studies after Mortimer (1941) have identified additional mechanisms for P mobilization in the sediment- water besides the DO (Søndergaard et al., 2003; Hupfer and Lewandowski, 2008; Kinsman-Costello et al., 2016).

Other factors potentially influencing sediment $\mathrm{P}$ 
retention in sediments include: quantity and quality of the organic carbon input, bioturbation by benthic macrofauna fluxes, communities and biomass of primary producers, rooted plants activity, sediment resuspension by winds and fish, sediment grain size, bacterial activity, among other sediment characteristics. Benthic fluxes or benthic organisms' activity can alter the structure and properties of the sediment, which further influences the flux of $\mathrm{P}$ from sediments to water column (Gachter and Meyer, 1993; Caliman et al., 2007; Chuai et al., 2013; Zhu et al., 2013; Kleeberg and Herzog, 2014; Benelli et al., 2018). Interactions (i.e., nutrient cycling and microphytobenthic community) between sediment and water column can also critically affect the magnitude and dynamics of $\mathrm{P}$ fluxes between sediments and water column (Wetzel, 2001; Katsev et al., 2006).

In this sense, the aim of the present study was to understand the temporal and spatial variation of $\mathrm{P}$ concentrations and its organic and inorganic forms in the sediments of a subtropical oligo-mesotrophic shallow lake and to assess if they are related to water column parameters (temperature, $\mathrm{pH}$, conductivity, DO, transparency, chlorophyll-a and total and dissolved nutrients and sediment characteristics (granulometry and benthic macrofauna). We expected to find:

Variation in P forms and concentrations in sediments determined by seasonal fluctuations in temperature via its effects on primary producers (chlorophyll $a$ ) and benthic macrofauna;

Spatial variation and concentration in $\mathrm{P}$ forms is associated with changes in sediments composition as well as grain size and sediment $\mathrm{OM}$;

A positive correlation between $P$ in the sediments and DO in the water column, and a negative correlation between $\mathrm{P}$ in the sediments and $\mathrm{pH}$, temperature and $\mathrm{P}$ concentration in the water.

\section{METHODS}

\section{Study area}

This study was performed in Peri Lake $\left(27^{\circ} 44^{\prime} \mathrm{S}\right.$ and $48^{\circ} 31^{\prime} \mathrm{W}$ ), a coastal lake, located in Southern Brazil, in the south-eastern portion of Santa Catarina island in the city of Florianópolis. The drainage basin is approximately $20 \mathrm{~km}^{2}$ and most of it is within a protected area (Municipal Park) since 1981 with limited anthropic pression. Since 2000 , the lake supplies potable water to approximately 100,000 people. Its surface area of 5.07 $\mathrm{km}^{2}$ is surrounded by mountains covered by Atlantic Rain Forest in the north, west and south portions, and by coastal restinga vegetation in the east. Peri Lake is considered a coastal lake due to the geographic location and geological origin (Holocene marine transgression), and presents maximum depth of $11 \mathrm{~m}$, and average depth of $4.2 \mathrm{~m}$. Two main streams (Cachoeira Grande and Ribeirao Grande streams), flow into the lake coming from the forested mountains and one channel (Sangradouro river) connects the lake with the ocean, that due to its morphological characteristics prevents any sea water intrusion, which makes Peri lake a freshwater system year-round (Fig. 1). The lake is the main freshwater resource of Florianópolis Island. The sediment is mainly composed of sand, and in the deeper regions the sediment is mainly clay and silt, which is associated with high levels of OM (Lemes-Silva et al., 2016). The lake is polymictic and presents a relative spatial homogeneity concerning water quality features (Hennemann and Petrucio, 2011). However, an increase in chlorophyll-a in Peri Lake has been recorded in recent years (Concentrations ranged from 4.3 to $59.8 \mu \mathrm{g} \mathrm{L}^{-1}$ (mean = $23.4 \pm 8.8 \mu \mathrm{g} \mathrm{L}^{-1}$ ); the annual average increased from 19.4 $\mu \mathrm{g} \mathrm{L}^{-1}(2010-2011)$ to $32.6 \mu \mathrm{g} \mathrm{L}^{-1}$ (2012-2013) and 20.9 $\mu \mathrm{g} \mathrm{L}^{-1}$ (October 2014-January 2015), as a result of decreasing rainfall and water level (Fuentes and Petrucio, 2015; Tonetta et al., 2017; Lemes-Silva et al., 2018), but dissolved nutrients remain in low levels (total $\mathrm{P}$ and $\mathrm{N}$ around $11.0 \mu \mathrm{g} . \mathrm{g}^{-1}$ and $0.9 \mu \mathrm{g} . \mathrm{g}^{-1}$, respectively) (Hennemann and Petrucio, 2011; Tonetta et al., 2016). The climate in the area is characteristically subtropical. The spring and summer months (mean $=276 \mathrm{~mm}$ ) are rainier than the winter months (mean $=56 \mathrm{~mm}$ ) due to the influence of the South American monsoon. Monthly mean air temperatures vary from 16.5 to $20^{\circ} \mathrm{C}$ during the winter (and between 23.0 and $26.5^{\circ} \mathrm{C}$ during the summer months (Tonetta et al., 2017; Lemes-Silva and Petrucio, 2018).

\section{Sampling and analysis}

The present study consisted of monthly sampling of physical, chemical and biological parameters in the water column and sediments in five sites (Fig. 1), during 26 months (March 2007 to May 2009). Site 1 (S1) was located in the centre of the lake, and was the deepest one $(8.0 \mathrm{~m})$; site 2 (S2) was $2.8 \mathrm{~m}$ deep and close to the discharge point of Cachoeira Grande Stream; site 3 (S3) was located near the outflow of Ribeirão Grande Stream, with a depth of $2.3 \mathrm{~m}$; site 4 (S4) was situated near the beach in the northeastern portion of the lake, with a 1.5 $\mathrm{m}$ depth; site 5 (S5) was $2.8 \mathrm{~m}$ deep, located in the extreme northern portion of Peri Lake. Site 5 was sampled from May 2008 to April 2009 (12 months).

Water column sampling was performed at Secchi disk depth using a $3 \mathrm{~L}$ van Dorn bottle for all the sites with the exception of the deepest site (S1) where four depths were sampled in order to evaluate vertical variations: surface, 10\% light penetration (Secchi depth), 1\% light penetration (three times Secchi depth), and aphotic zone (middle point between lake bottom and three times Secchi depth). Water 
temperature (WT), conductivity (Cond), $\mathrm{pH}$ and dissolved oxygen concentration (DO) were measured in situ with specific probes (WTW-Multi350i). Nitrite (NO2; Golterman et al., 1978), nitrate $\left(\mathrm{NO}_{3}\right.$, Mackereth et al., 1978), ammonium (NH4; Koroleff, 1976), soluble reactive phosphorus (SRP; Strickland and Parsons, 1960) and total phosphorus and nitrogen (TP and TN-Valderrama 1981) concentrations were determined in laboratory from filtered and unfiltered water samples kept in polyethylene bottles at $-20^{\circ} \mathrm{C}$. The filtered and unfiltered samples were frozen until being analyzed for nutrients. Before analysis, the samples were completely thawed while kept in into dark boxes until being analyzed within $24 \mathrm{~h}$. Chlorophylla $(\mathrm{Chl}$ a) concentration was determined by filtering $500 \mathrm{~mL}$ water samples through glass fibre filters Millipore AP40 followed by extraction with $90 \%$ acetone according to the method and equations described by Lorenzen (1967). Daily precipitation, air temperature and wind speed (mean and max) data was provided by ICEA ("Instituto de Controle do Espaço Aéreo") from the Defence Ministry, Brazilian Federal Government located on Florianópolis airport station (5.5 km from Lake Peri).

Sediment samples were collected monthly right after water samples at the same five sampling sites using an Ekman-Birge graber $\left(15 \mathrm{x} 15 \mathrm{~cm}, 0.0225 \mathrm{~m}^{2}\right)$. At each sampling site, four samples were collected for analysis of aquatic macrobenthic and three samples were taken for sediment analyses (mean grain size, percentage of organic matter and phosphorus contents). In the laboratory, the 240 macrobenthic samples were washed under water jets, using $0.250 \mathrm{~mm}$ mesh sieves and all macrobenthic retained in the mesh were sorted, counted and preserved in $70 \%$ alcohol. The aquatic fauna was sorted under microscope and identified to the lowest taxonomic level possible. The organisms belonging to Chironomidae family were mounted on semi-permanent slides and subsequently identified, under stereomicroscope, using appropriate literature (Epler, 1995; Trivinho-Strixino and Strixino 1995). Sediment granulometric fraction and distribution was measured by standard dry-sieve method following the Wentworth scale with nest of sieves (form $2.8 \mathrm{~mm}$ to $<0.062 \mu \mathrm{m}$ ) divided into eleven steps (Suguio 1973). Organic matter (OM) content was estimated by weight loss on ignition $(7 \mathrm{~g}$ sediment, $550^{\circ} \mathrm{C} / 4 \mathrm{hs}$ ), as described by Engstrom et al. (2009). Total phosphorus (TP) was determined as phosphate with

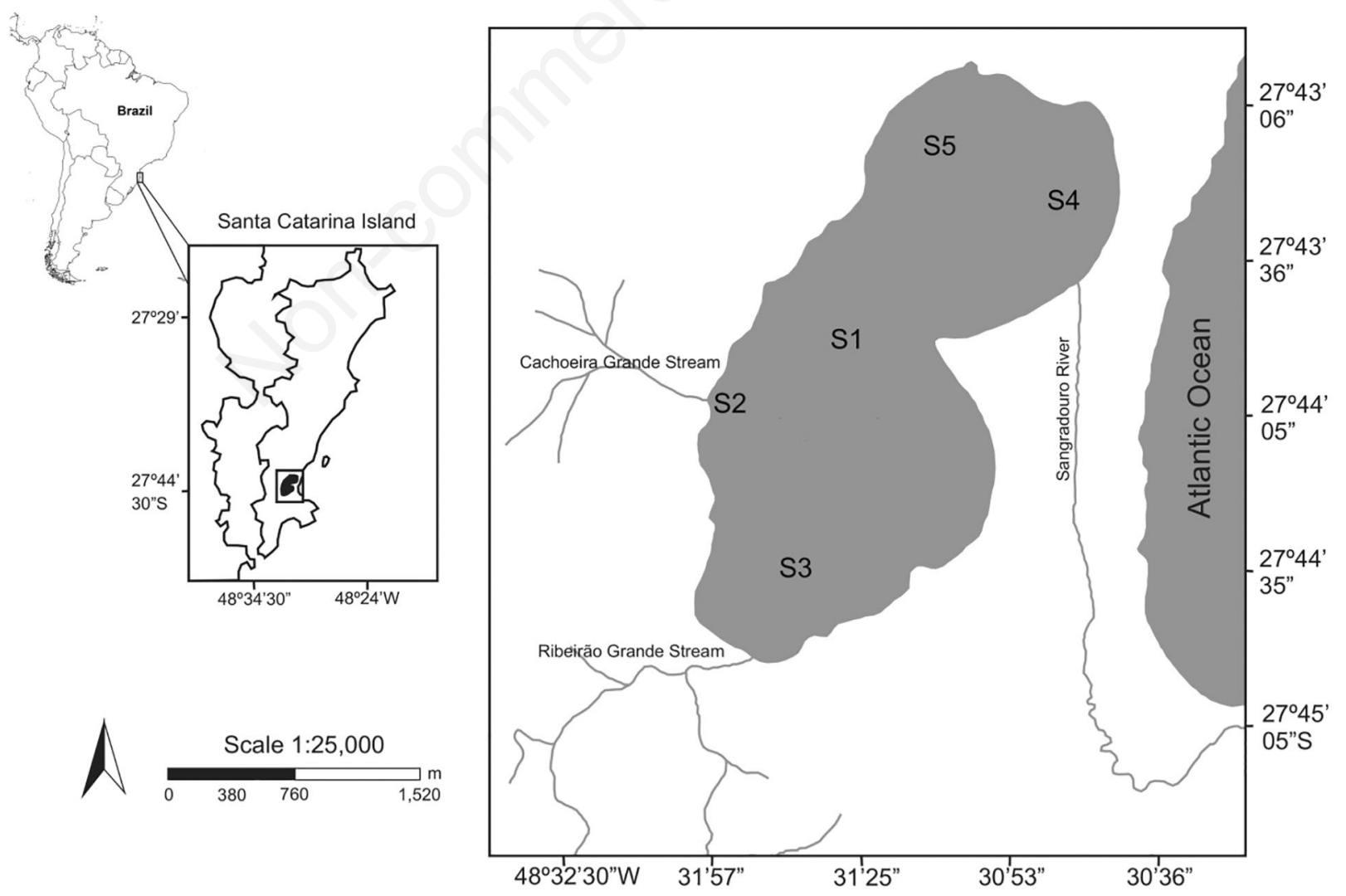

Fig. 1. Geographical location of Peri Lake showing the 5 sampling sites (Lemes-Silva et al., 2016). The grey area delimitates the watershed and shows the two main rivers flowing into the lake and the outflowing channel to the ocean. 
ammonium molybdate and ascorbic acid reaction in spectrophotometer (Koroleff 1976) after combustion (muffle furnace, $550^{\circ} \mathrm{C}$ for $1: 30 \mathrm{~h}$ ) and $\mathrm{HCl}$ extraction (Aspila et al., 1976). Inorganic phosphorus (IP) was determined similarly to TP, but no combustion was made previously to the $\mathrm{HCl}$ extraction (Aspila et al., 1976). Organic phosphorus (OP) was calculated from subtraction of IP from TP. Proportion of OP in relation to TP $(\% \mathrm{OP})$ was calculated as OP divided by TP.

\section{Statistical analysis}

Temporal and spatial variation concerning TP, IP, OP, $\% \mathrm{OP}$ and $\mathrm{OM}$ content in the sediments were tested by oneway Analysis of Variance (ANOVA), followed by Tukey post-hoc. Prior to the analysis, all data normality was assessed with the Kolmogorov-Smirnov test, the homogeneity of variances was assessed with Levene's test, and values were transformed $(\log x+1)$ if needed. Pearson's correlation was applied between sediment characteristics and water column parameters and climate data of the seven days previous to sampling dates, in order to verify the way and amount of linear relationship between parameter. Statistical analyses and graphs were made in the R-Program ver. 3.2.2 and Statistica $7^{\circledR}$ (StatSoft). Non-metric multidimensional scaling (NMDS, vegan package), using Euclidian distance matrices, was performed to explore broad spatial between TP, OP and OM and four sediment grain size categories (silt, fine sand, medium sand and coarse sand) among all sampled sites. When the stress value was in the range of zero to 0.1 , the two-dimensional representation was sufficient to distinguish the groups formed in relation to grain size and TP, OP and OM values (Clarke and Warwick 2001). Multiple regression analysis was conducted to examine the relationship between TP, OP and $\mathrm{OM}$ and seven benthic functional feeding groups (predators, collectors, filtering-collectors, filterers, scrapers, shredders, gatherer-collectors). We evaluated the plausibility of each model by Akaike's model selection criterion, which selects the model closest to the "real" process underlying the biological phenomenon under study (Burnham and Anderson, 2002). Grain size and benthic community information were taken from LemesSilva et al. (2016) and Lisboa et al. (2011).

\section{RESULTS}

\section{Temporal and spatial variation in sediment $\mathbf{P}$}

The TP concentration in the sediments of Peri Lake varied from 17.1 to $1452.4 \mu \mathrm{g} \mathrm{g}^{-1}$ (mean: $479.9 \mu \mathrm{g} \mathrm{g}^{-1}$ ) and was significantly different $\left(\mathrm{F}_{4.250}=306.1, \mathrm{P}=0.0001\right)$ among the five sampled sites (Fig. 2) with $\mathrm{S} 1>\mathrm{S} 3>\mathrm{S} 2>\mathrm{S} 5>$ $\mathrm{S} 4$. The OP content prevailed in all sites in relation to IP, with mean $\% \mathrm{OP}$ higher than $60 \%$; site 4 showed the lowest
OP proportion among all sampled stations. The \%OP only differed significantly $\left(\mathrm{F}_{4.250}=10.23, \mathrm{P}=0.0011\right)$ between site 4 and the other sampled sites (except site 5). On the other hand, OM content of the sediments in Peri Lake was significantly different $\left(\mathrm{F}_{4.250}=111.3, \mathrm{P}=0.0001\right)$ in all sampled sites (Fig. 3). Sites 2 and 3 showed similar OM content and site 4 showed the lowest OM content. Concerning temporal variation in $\mathrm{P}$ content in the sediments of Peri Lake (Fig. 4), sites 1, 2 and 3 showed similar temporal variation patterns, generally with lower TP concentrations and lower OP content in July, August and September months. In general, \%OP was lower in 2007 seasons when compared to seasons in 2008 for all sites (except site 5).

\section{Correlations of sediment $P$ with meteorological and water column parameters}

Correlations of $\mathrm{P}$ content in the sediment, including TP, IP, OP and \%OP, along the study period with water quality parameters were conducted for each sampling site (Tab. 1) in order to better understand which factors could be influencing the temporal variation in sediment $\mathrm{P}$ forms in Peri Lake. Climate data, dissolved nutrients (except for nitrate), TN and Secchi depth were not correlated with any of the sediment $\mathrm{P}$ forms and are therefore not shown in Tab. 1. Sediment $\mathrm{P}$ in site 5 was also not correlated to any of the climate data nor to the water column parameters and is also not shown.

Total phosphorus in the sediments was positively correlated with Chl- $a$ in site 1, with DO and $\mathrm{pH}$ in site 3, and negatively with $\mathrm{NO}_{3}$ in site 2 . Inorganic phosphorus was positively correlated with $\mathrm{DO}$ and $\mathrm{NO}_{3}$ in sites 1,3 and 4 , and negatively with $\mathrm{pH}$ in site 4 , and with TP in the water in all sites. Organic phosphorus showed a positive correlation with Chl- $a$ in site 1 , with water temperature and $\mathrm{pH}$ in site 3 , and with $\mathrm{TP}$ in the water in

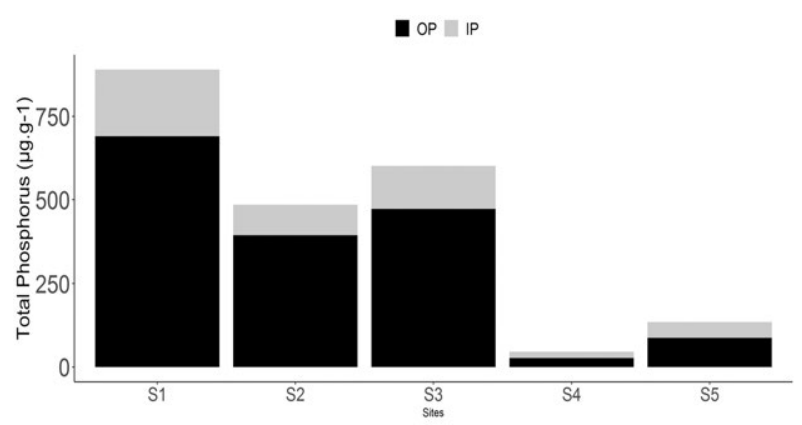

Fig. 2. Mean total phosphorus content in the sediments of Peri Lake, in $\mu \mathrm{g} \mathrm{g}^{-1}$, in the five sampling sites, with differentiation between organic phosphorus (OP, black), and inorganic phosphorus (IP, grey), along the study period (March 2007May 2009). 
site 4. Negative correlations with OP were only observed in site 2 with $\mathrm{NO}_{3}$. Percent of OP was positively correlated with water temperature in sites 1 and 3 , and with Chl- $a$ and TP in the water in sites 1,3 and 4. A negative correlation was observed between $\% \mathrm{OP}$ and $\mathrm{DO}$ in sites 1,3 and 4, and with $\mathrm{NO}_{3}$ in sites 2, 3 and 4.

\section{Influence of grain size and benthic fauna on sediment $P$}

The grain size in Peri Lake varied from gravel to silt and clay and was significantly different among the five sampled sites. The major differences occurred between the marginal sites (S2, S3 and S5) (coarse, medium and fine sands), the centre of the lake (S1) (fine grains) and areas in the north-eastern portion of the lake (S4) (fine sand). NMDS with sediment particle size and P forms related to sampling sites (Fig. 5) shows that sites 1,2 and 3 are very similar, showing a higher silt content (33.5\%), and sites 4 and 5 have higher fine and medium sand contents $(2.1 \%)$. Site 4 had greater fine sand content while site 5 showed a higher medium sand proportion compared to other sites. The NMDS also shows that the sites with the higher silt content (centre of the lagoon (S1$33.5 \%$ ) and in the regions near aquatic vegetation ( $\mathrm{S} 1$ and S2-33.1 \%) are also the sites with the higher TP, OP and

Tab. 1. Pearson's correlation between TP, IP, OP and \%OP in the sediments and water column parameters for sampling sites $1,2,3$ and 4, in Peri Lake, along the study period (March 2007 - May 2009). Significant correlations $(\mathrm{P}<0.05)$ are marked in bold.

\begin{tabular}{|c|c|c|c|c|c|c|c|}
\hline & & W Temp & $\mathrm{pH}$ & DO & Chl-a & $\mathrm{TPw}$ & NO3 \\
\hline \multirow[t]{4}{*}{ S1 } & $\mathrm{TP}$ & 0.19 & 0.17 & 0.14 & 0.52 & -0.15 & 0.27 \\
\hline & IP & -0.12 & 0.13 & 0.41 & 0.17 & -0.51 & 0.53 \\
\hline & $\mathrm{OP}$ & 0.26 & 0.15 & 0.04 & 0.60 & -0.07 & 0.10 \\
\hline & $\% \mathrm{OP}$ & 0.48 & 0.04 & -0.49 & 0.67 & 0.51 & -0.39 \\
\hline \multirow[t]{4}{*}{$\mathrm{S} 2$} & TP & -0.03 & -0.22 & 0.21 & 0.20 & -0.23 & -0.53 \\
\hline & IP & -0.35 & -0.21 & 0.17 & -0.07 & -0.44 & 0.10 \\
\hline & OP & 0.10 & -0.18 & 0.19 & 0.24 & -0.03 & -0.56 \\
\hline & $\% \mathrm{OP}$ & 0.36 & -0.03 & 0.07 & 0.23 & 0.25 & -0.56 \\
\hline \multirow[t]{4}{*}{ S3 } & $\mathrm{TP}$ & -0.26 & 0.47 & 0.41 & 0.05 & 0.05 & -0.10 \\
\hline & IP & -0.28 & 0.12 & 0.59 & -0.36 & -0.41 & 0.42 \\
\hline & OP & 0.47 & 0.46 & 0.12 & 0.25 & 0.28 & -0.26 \\
\hline & $\% \mathrm{OP}$ & 0.45 & 0.08 & -0.53 & 0.43 & 0.41 & -0.42 \\
\hline \multirow[t]{4}{*}{ S4 } & TP & -0.09 & -0.36 & 0.05 & 0.04 & 0.03 & 0.18 \\
\hline & IP & -0.29 & -0.44 & 0.44 & -0.36 & -0.47 & 0.55 \\
\hline & OP & 0.26 & -0.12 & -0.41 & 0.33 & 0.53 & -0.18 \\
\hline & $\% \mathrm{OP}$ & 0.40 & 0.25 & -0.58 & 0.45 & 0.66 & -0.49 \\
\hline
\end{tabular}

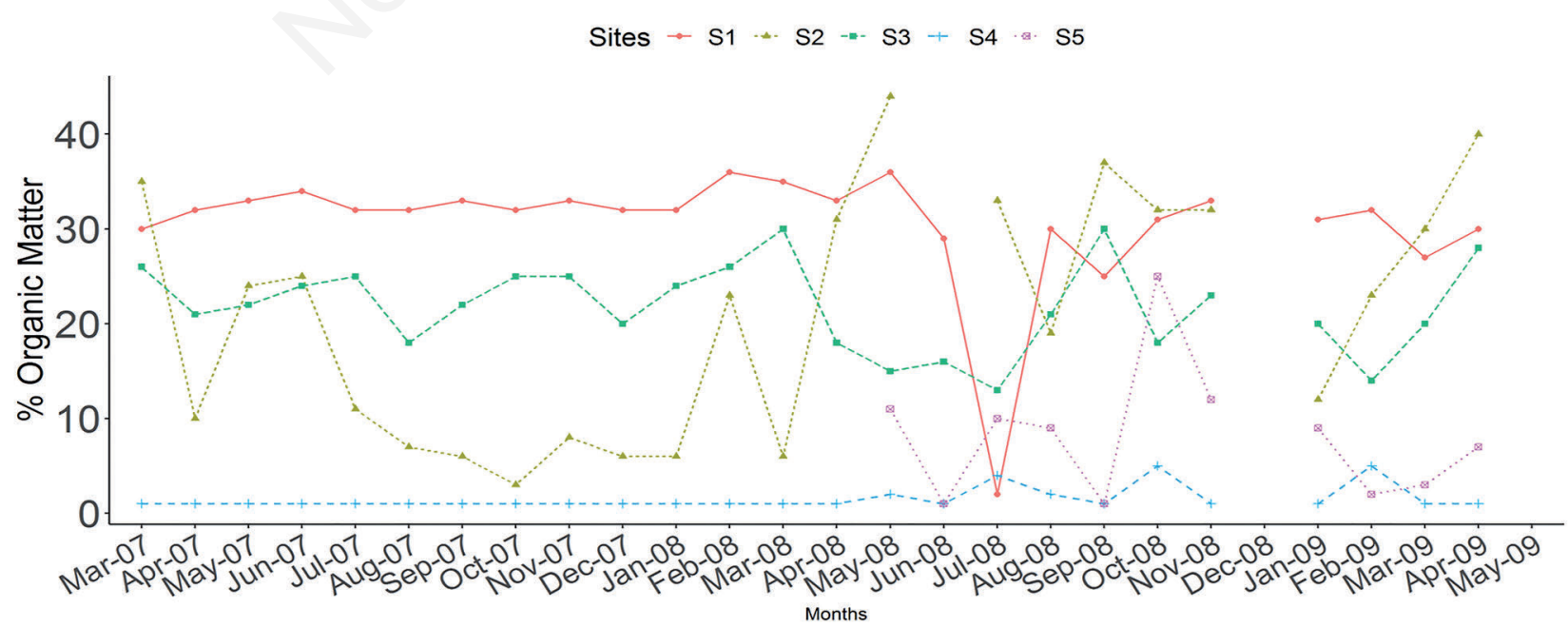

Fig. 3. Monthly organic matter content in the sediments of Peri lake, in percentage, in the five sampling sites along the study period (March 2007-May 2009). 
Total Phosphorus $\square$ IP $\mathbf{D}$ OP

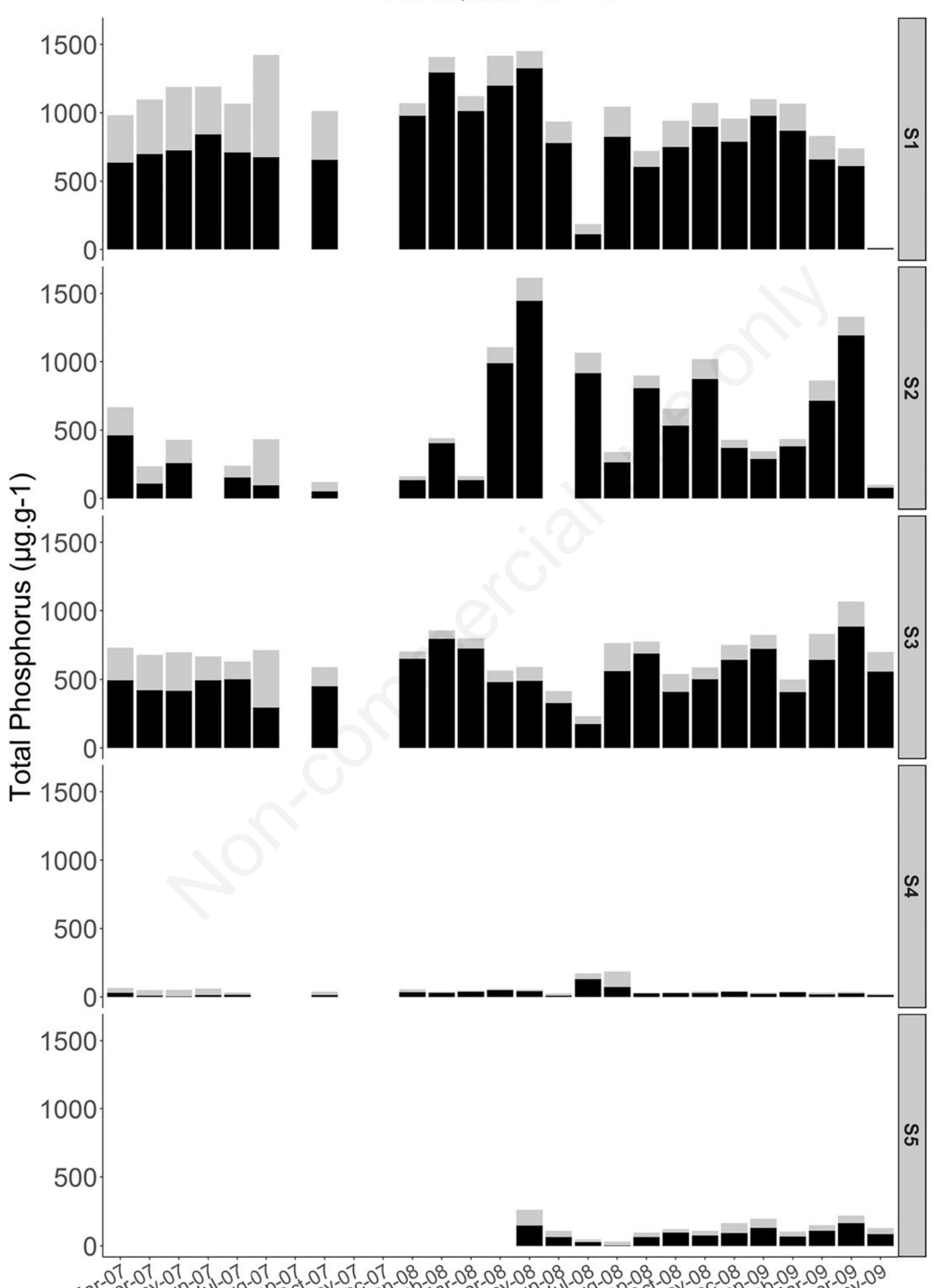

Fig. 4. Monthly total phosphorus content in Peri Lake sediments in $\mu \mathrm{g} \mathrm{g}^{-1}$, in the sites sampled with differentiation between organic phosphorus (OP, black) and inorganic phosphorus (IP, grey), along the study period (March 2007-May 2009). 
OM contents. Multiple regression analysis between TP, $\mathrm{OP}$ and $\mathrm{OM}$ and the seven benthic functional feeding groups for each sampling site is shown in Tab. 2. For site 1 , neither OM nor TP and OP were related to any of the seven functional groups. In site 2, TP was negatively affected by gathering-collectors and filtering-collectors, while $\mathrm{OP}$ and $\mathrm{OM}$ were negatively affected by gatheringcollectors and positively affected by filtering-collectors. In site 3, TP, OP and OM were positively influenced by shredders. Differently, for site 4, filtering-collectors were positively related to TP, while OP was positively related to filterers, and OM was not affected by any feeding group. Site 5 showed a positive relationship between OP and filterers, but no relationship between TP and OM and the seven benthic functional feeding groups.

\section{DISCUSSION}

\section{Temporal and spatial variation in sediment $P$}

TP concentration in the sediments of the five sampling sites in Peri Lake was higher in $\mathrm{S} 1>\mathrm{S} 3>\mathrm{S} 2>\mathrm{S} 5>\mathrm{S} 4$, which was closely associated to OM content in each site, showing that most of the $\mathrm{P}$ in the sediments is stored inside living cells and in organic detritus materials. The composition and TP content of sediment samples also showed substantial spatial heterogeneity as in other shallow lakes (Liu et al., 2012; Kangur et al., 2013). This horizontal differences in sediment TP within the lake can be associated to macrofauna, sediment granulometry, debris from fauna and flora, water depth, wind influence, among others (Doremus and Clesceri, 1982; Gachter and Meyer, 1993; Lijklema, 1993; Kleeberg and Dudel, 1997; An and Li, 2009).

Doremus and Clesceri (1982) showed that four times more $\mathrm{P}$ promote sequestration of $\mathrm{P}$ in sediments in oligotrophic Lake George. The results of their experiments also suggest that microbial activity and $\mathrm{OM}$, including non-living detritus, aid in the immobilization of $\mathrm{P}$ in sediments. In this sense, the higher content of $\mathrm{OM}$ and silt in sites 1, 2 and 3 in Peri Lake probably explain their higher $\mathrm{P}$ content when comparing S4 versus S5.

Besides grain size composition, different quantities and qualities of sediment bacteria may also have influenced in differences in TP, OP and IP content in Peri Lake. Gachter and Meyer (1993) have long demonstrated the importance of bacteria in sediment $\mathrm{P}$ content, showing

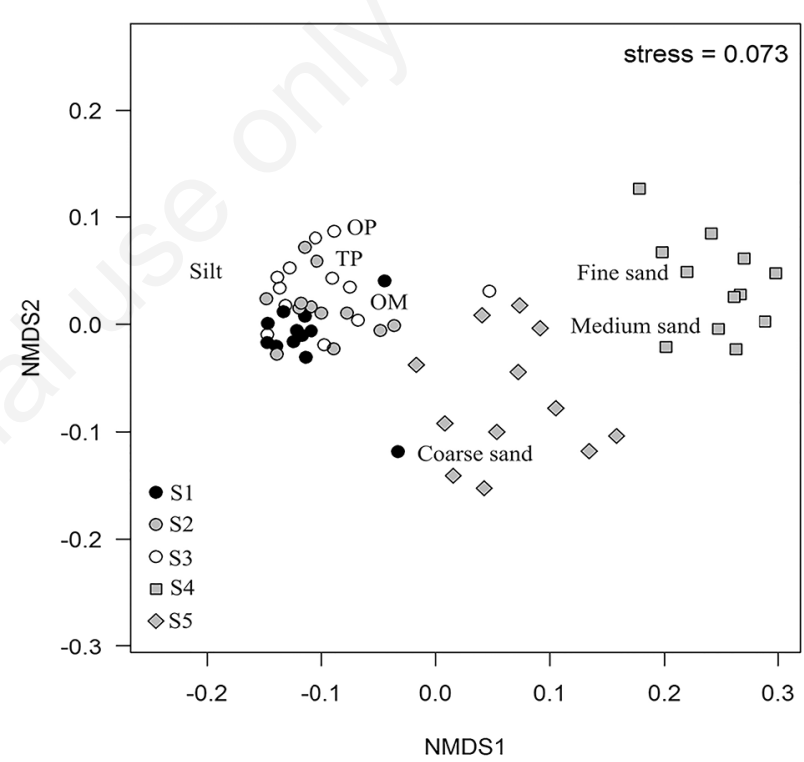

Fig. 5. NMDS of the five sampling sites considering grain size categories (silt, fine sand, medium sand and coarse sand), phosphorus forms (TP, OP) and the organic matter (OM) content.

Tab. 2. Results of the multiple regression analysis between TP, OP and OM and the seven benthic functional feeding groups for each sampling site. Only models selected by Akaike's criterion are shown.

\begin{tabular}{|c|c|c|c|c|c|c|c|c|c|}
\hline \multirow[b]{2}{*}{ S 2} & \multicolumn{3}{|c|}{ Total phosphorus } & \multicolumn{3}{|c|}{ Organic phosphorus } & \multicolumn{3}{|c|}{ Organic matter } \\
\hline & Slope & F & $\mathbf{P}$ & Slope & F & $\mathbf{P}$ & Slope & F & $\mathbf{P}$ \\
\hline Gathering-collectors & -1141.4 & 18.801 & 0.002 & -1025 & 17.215 & 0.003 & -0.178 & 11.04 & 0.009 \\
\hline Filtering-collectors & -334.1 & 6.968 & 0.030 & 302.2 & 6.563 & 0.033 & 0.100 & 12.04 & 0.007 \\
\hline \multicolumn{10}{|l|}{ S3 } \\
\hline Shredders & 86.01 & 7.191 & 0.023 & 74.95 & 7.236 & 0.022 & 0.056 & 7.021 & 0.033 \\
\hline \multicolumn{10}{|l|}{ S 4} \\
\hline Filtering-collectors & 17.176 & 8.161 & 0.029 & & & & & & \\
\hline Filterers & & & & 0.607 & 27.551 & 0.012 & & & \\
\hline \multicolumn{10}{|l|}{ S 5} \\
\hline Filterers & & & & 0.707 & 18.391 & 0.001 & & & \\
\hline
\end{tabular}


that these organisms also depend on $\mathrm{P}$ as a nutrient and are able to take it up from the substrate or from the water. A substantial part of the $\mathrm{P}$ might be incorporated in bacterial biomass and the net release can be controlled by bacterial demand for $P$.

The mineralization of organic material also influences in the $\mathrm{P}$ content of sediments, and since OM comes from various sources, with variable phosphate contents and biodegradability (Lijklema, 1993), it can also influence the spatial P heterogeneity. In Peri Lake, detritus input has shown large difference along the shore, related to differences in macrophyte stands presence (Panicum aquaticus, Commelina diffusa, Nymphoides indica and Schoenoplectus californicus), proximity to the discharge points of rivers, litter from the littoral zone (Pieczynska, 1993; Hennemann et al., 2015; Lemes-Silva et al., 2018), and differences in sampling site depth (different light availability). All these factors may be important in influencing the quality of $\mathrm{OM}$ sources and rates of mineralization, contributing to the observed differences in $\mathrm{P}$ content among sites.

It is important to highlight that differences in P content observed in the sediments were not reflected in water column TP and SRP concentration, since Hennemann and Petrucio (2011) have already demonstrated that there are no significant differences among the same sampling sites concerning water quality parameters, in a similar period. This is probably due to the shallow depths observed in the Peri lake and relatively frequent wind influence in this coastal water body (average wind speed was $3.3 \pm 2.69 \mathrm{~m}$ $\mathrm{s}^{-1}$ ). Wind velocities higher than $4 \mathrm{~ms}^{-1}$ are capable of completely mixing a water body to a depth of $6 \mathrm{~m}$, by creating waves and circulation currents (Kleeberg and Dudel, 1997). Concerning the temporal variability in sediment P in Peri Lake, according to Lijklema (1993), within a year the sediment matrix will be fairly constant except for the pool of non-refractory organic material. Consequently, the adsorptive capacity of the sediment for phosphate varies mainly due to changes in redox conditions related to the temperature cycle and the course of organic deposition. Phosphate in microbial biomass and iron associated phosphate can be important as transient pools since they are influenced by temperature and redox conditions (Caraco, 1993; Montigny and Prairie, 1993).

Burger et al. (2007) attributed the large seasonal differences in release rates observed in shallow polymictic Lake Rotorua (New Zealand) in part to variable sedimentation rates and to changes in temperature, which controls rates of biological activity, oxygen consumption and redox potential. Although seasonal differences were not as large in Peri Lake, the temporal variation observed can also be associated to variable sedimentation rates (influenced by shallowness and wind), temperatures and DO concentration in the sediment-water interface.
A complex of climatic, hydrological as well as hydrochemical factors was regarded as the cause of differences observed in P release from sediments in 1992 and 1993 in Lake Müggelsee (Germany; Kleeberg and Dudel, 1997). Differences in water temperature, which influences biological processes and especially DO concentration in the water, was the probable explanation for the differences in P release between the two years. Differences between years were also observed in our study, especially in \%OP. According to Kangur et al. (2013), feedback in the P cycling can also have an important effect in increasing short term temporal differences: an increase in P release from the sediments leads to increase primary production in the water column, which can increase OM sedimentation flux, which increases the amount of OP and the rates of oxygen and ferric oxyhydroxide consumption in the sediment, which, in turn, further increases the release of $\mathrm{P}$ from the sediments. Correlations between sediment $P$ characteristics and meteorological and water column parameters along the studied period could improve our understanding of factors driving the temporal $\mathrm{P}$ dynamic in Peri Lake and will be discussed in the next section.

\section{Correlations of sediment $P$ with climate and water column parameters}

Water temperature had a positive influence on the OP content in Peri Lake sediments. The effect of temperature on $\mathrm{P}$ concentration in the sediments has been demonstrated in several studies. Jensen and Andersen (1992) found that water temperature alone could explain nearly $70 \%$ of the seasonal variation in sediment $P$ release in three shallow eutrophic lakes. Kleeberg and Dudel (1997) associated increasing temperatures with higher aerobic mineralization processes and consequently lower DO in the water column, which can increase P release from the sediments. Spears et al. (2006) also associated high temperatures to elevated $\mathrm{O}_{2}$ consumption by bacteria, which temporally removes the oxygenated surface layer and releases P to the water column. In the P-limited Peri Lake, enhanced IP release from the sediments (increasing $\% \mathrm{OP}$ ) associated to higher $\mathrm{O}_{2}$ consumption and lower DO solubility with higher temperatures is capable of increasing primary production in the water column, which results in higher OM deposition, further increasing the $\mathrm{OP}$ content. Higher temperatures also stimulate conversion of IP in OP by benthic primary producers, increasing OP content in the sediments even more. Wu et al. (2014) presented a similar explanation for the temperature effects on $\mathrm{P}$ release from shallow Lake Xuanwu (China) sediments in their laboratory experiments. According to the authors conclusion, the higher the temperature, the more $\mathrm{P}$ is released and the longer the time to achieve equilibrium of release. 
As observed in Peri Lake, no substantial difference between the DO concentration in surface and near-bottom water was detected in summer in shallow polymictic Lake Peipsi (Kangur et al., 2013). In this sense, we can assume the entire water column was well oxygenated in the sampling days. The negative correlations found in summer DO concentrations in the water with sediment OP and TP concentrations in Lake Peipsi (Kangur et al., 2013) are similar to the negative correlations found between DO and $\% \mathrm{OP}$ in Peri Lake. This result can be a consequence of higher temperatures in summer, which decreases DO solubility and increases assimilation of $\mathrm{P}$ by primary producers and bacteria, what increases \%OP in the sediments, as previously discussed. On the other hand, IP in the sediments of Peri Lake was positively correlated to DO. A higher DO concentration in the overlying water generally decreases $\mathrm{P}$ effluxes from sediments (Kangur et al., 2013), which can maintain a higher IP content trapped in the sediments. Results found in both Lake Peipsi and Peri Lake show that variation in DO concentration in the water column can significantly affect $P$ release rates from the sediments.

Concerning $\mathrm{pH}$ correlations with $\mathrm{P}$ forms (site 4) $\mathrm{pH}$ showed a negative correlation with IP, what indicates that in this site with low OM content, increase in $\mathrm{pH}$ may be leading to IP release from the sediments. Indeed, according to Boers (1991), a higher $\mathrm{pH}$ causes the desorption of phosphate from $\mathrm{Fe}^{3+}$ hydroxides, resulting in a release of phosphate from the sediments. Boers (1991) also affirmed that enhanced photosynthetic activity can lead to higher $\mathrm{pH}$ by withdrawing $\mathrm{CO}_{2}$ from the water and shifting the $\mathrm{CO}_{2} / \mathrm{HCO}^{-} / \mathrm{CO}^{-}$equilibrium. In this sense, the positive correlation observed between TP/OP with $\mathrm{pH}$ in site 3 could be associated with higher primary production in warmer months, which increased $\mathrm{pH}$ and $\mathrm{TP} / \mathrm{OP}$ accumulation in the sediments.

The positive correlation of $\mathrm{NO}_{3}$ with IP in sites 1,3 and 4 can be associated to the effect that $\mathrm{NO}_{3}$ has in the $\mathrm{P}$ cycling through its influence on the iron cycling. According to Caraco (1993), the presence of $\mathrm{NO}_{3}$ can indirectly inhibit $P$ release from sediments, since $\mathrm{NO}_{3}$ can inhibit the reduction of oxidized iron $\left(\mathrm{Fe}^{3+}\right)$ to the reduced form $\left(\mathrm{Fe}^{2+}\right)$, maintaining higher $\mathrm{Fe}^{3+}$ levels and preventing $\mathrm{P}$ release. Conversely, the OP content in the sediments showed a negative correlation with $\mathrm{NO}_{3}$ in sites 2, 3 and 4 , which could be associated to temperature, since it is capable of increasing bacterial denitrification processes (consuming $\mathrm{NO}_{3}$ ) and increase $\mathrm{OP}$ content in the sediments as previously discussed. Jensen and Andersen (1992) argued that $\mathrm{NO}_{3}$ concentration could reduce $\mathrm{P}$ release in winter and early summer, but increase it in late summer. In other words: $\mathrm{NO}_{3}$ can have different effects on P release depending on seasonal aspects (especially temperature), as apparently happens also in Peri Lake.
Total phosphorus concentration in the water column showed a negative correlation with IP in the sediments in the four sampled sites showed in Tab. 1. This can also be an effect of temperature, since higher temperatures can increase IP release from the sediments to the water column (by increasing mineralization rates and decreasing $\mathrm{DO})$, stimulating primary production and increasing TP concentration in the water. Increased IP release from the sediments and OM production and deposition from the water column associated to higher temperatures both contribute to the positive correlation observed between $\mathrm{TP}$ in the water and $\% \mathrm{OP}$ in the sediments.

As can be concluded from the discussion above, temperature and DO in the water column seem to be critical in sediment $\mathrm{P}$ fluxes in Peri Lake. According to Gachter and Meyer (1993), if the sediment surface of a lake is permanently oxic, it will accumulate $\mathrm{P}$ until its $\mathrm{P}$ content reaches its $\mathrm{P}$ binding capacity, and then, the sediment would start to release $\mathrm{P}$ even under oxic conditions. Relatively high $\mathrm{P}$ content in Peri Lake sediments and the well oxygenated water column may be an indication that the system is accumulating $P$ in the sediments. When it reaches the P-binding capacity, higher P release rates are probable, which can have dramatic consequences to this P-limited lake dominated by potentially toxic Cyanobacteria.

\section{Influence of grain size and benthic fauna on sediment $P$}

The higher TP, OP and OM content in sites with higher silt content found in Peri Lake was expected, since studies have shown that the $\mathrm{P}$ adsorption rate increases with the increase in fine particles of the sediments, due to high surface area, and that sorption rates are mainly affected by the percentage of fine particles less than $63 \mu \mathrm{m}$ (An and Li, 2009; Zhu et al., 2013). Heterogeneity in particles spatial distribution in the lake can be influenced not only by depth and proximity to margins and rivers discharge points, but can also reflect the impact of water currents in the lake (Kangur et al., 2013).

Concerning relationships found between TP, OP and $\mathrm{OM}$ and the seven macroinvertebrates feeding groups in each sampling site, they could represent only an indirect effect related to seasonal temperature variation, but they may also represent an important influence of the benthic organisms in the $\mathrm{P}$ cycling in the sediment-water interface, since studies have shown that macroinvertebrates can have strong relationships with $\mathrm{P}$ in the sediments (Wazbinzki and Quinlan, 2013; Zhang et al., 2014).

In site 1 , no significant relationship was identified by the multiple regression analysis followed by selection of the best model by Akaike's criterion. This could be related to the deepness of this sampling site $(\sim 8 \mathrm{~m})$, absence of light and low richness in the macroinvertebrate community (Lemes-Silva et al., 2016). The deep regions 
of aquatic ecosystems have restrictions limiting the development of some species due to the decrease of light penetration in the water column and many aquatic organisms not adapting to the prevailing conditions (Pech et al., 2007), which may explain the very poor species number in this site with dominance of tolerant taxa such as oligochaetes.

In site 2, both $\mathrm{P}$ forms and $\mathrm{OM}$ were negatively affected by gathering-collectors, and positively affected by filtering-collectors. Gathering-collectors feeding on fine particles OM in the sediments (Merrit and Cummins, 1984; Cummins et al., 2005) move through the sediments actively, and could be moving and resuspending sediments and breaking the oxic surface layer, releasing $\mathrm{P}$ from the sediments to the water column. On the other hand, filtering-collectors remain buried in the sediment, collecting and filtering materials from the sediment surface and bottom waters, and excreting inside the sediment matrix, which could be increasing $\mathrm{P}$ and $\mathrm{OM}$ content in the sediments (Malmqvist et al., 2002).

Shredders influenced TP, OP and OM positively in site 3. This feeding group feeds on leaves and other organic material, such as wood, needles and fruits by biting into them or by cutting or boring through them. So, shredders excrete materials usually composed of particles that are smaller and of a different quality than what they ingest (Tomanova and Usseglio-Polatera, 2007), facilitating incorporation of these materials in the sediments and their use by smaller organisms, increasing $\mathrm{P}$ and $\mathrm{OM}$ in this site.

Differently, for site 4, which showed a very low OM content, and higher fine sand proportion, the benthic community was poor, dominated mainly by Tanaidacea (gathering-collectors) and Diptera larvae of Lopescladius sp. (filterer). Gathering-collectors are organisms adapted to feed on fine particles deposited on the substrate surface (Wallace and Webster, 1996) and filterers are organisms adapted to feed on particles in suspension. Some filter feeders (Simuliidae, Chironomidae and Philopotamidae) and gathering-collectors (Tanaidacea and Oligochaeta) may increase the quantity of $\mathrm{OM}$ in the environment by ingesting minute particles and egesting compacted faecal particles larger than those originally consumed. Thus, these animals may perform two very important functions: i) the removal of fine particles of OM from suspension (which would otherwise pass unused through that area); and ii) the supply of larger particles via their faeces to a broad spectrum of deposit-feeding detritivores (Wallace and Webster 1996). The positive relationship between OP and filterers in site 5 could be associated to P-rich excretion in the sediments by filterers taking particles from the bottom waters, which is increased and stimulated by higher benthic activities in warmer temperatures. This site is rich in suspended OM from leaves and has a higher fine and coarse sand proportion.

\section{CONCLUSIONS}

We can conclude that: i) $\mathrm{P}$ forms and concentration varied among the sampling sites, probably associated with different silt contents, depth of the water column, bacterial and macroinvertebrates quantity and composition; most of the $\mathrm{P}$ was in organic form, so sites with higher OM content showed higher P contents as well. P forms and concentration also varied seasonally, with $\mathrm{OP}$ and TP increasing in the sediments in warmer periods (especially spring and summer), as a result of higher primary production and decomposition rates; effects of temperature in other parameters, such as $\mathrm{DO}$ and $\mathrm{pH}$, could also increase its influence on seasonal P dynamics. ii) Quantities and qualities of $P$ in the sediments were correlated with water characteristics, especially temperature, $\mathrm{Chl}-a, \mathrm{NO}_{3}, \mathrm{DO}, \mathrm{pH}$ and TP; temperature has probably both a direct effect through stimulation of primary production and decomposition, and an indirect effect through its effect on other variables $\left(\mathrm{DO}, \mathrm{pH}, \mathrm{NO}_{3}\right)$; DO concentration in the water column also plays a fundamental role in sediment P dynamics in shallow Peri Lake. iii) Some benthic functional feeding groups showed significant relationships with temporal variation in sediment $\mathrm{P}$, including gathering-collectors, shredders and filterers and filtering-collectors; their behaviour and feeding habitats could be associated with the kind of the relationship identified (positive or negative).

These results offer strong evidence to suggest the importance of temperature mediated control of sedimentP release, through its direct effects in primary production and decomposition rates, and also indirect influence through its effects on other water and sediment characteristics, especially DO concentration in the water. The results obtained in the present study should improve our understanding on how shallow lake systems and sediment $\mathrm{P}$ content may respond to changes in water quality parameters in the future. Further studies including in situ and laboratory experiments are needed to better understand the relationships found and to develop management strategies under different land use and climate change scenarios.

\section{ACKNOWLEDGMENTS}

We are thankful to researchers from the "Laboratório de Ecologia de Águas Continentais" (www.limnos.ufsc.br), "Laboratório de Biologia e Cultivo de Peixes de Água Doce" and "Núcleo de Estudos do Mar" for field and laboratory assistance. We thank the PPGECO - UFSC (Programa de Pós-Graduação em Ecologia) for providing assistance for field and laboratory equipments. ALLS was supported by a post-doctoral grant awarded by 
Coordenação de Aperfeiçoamento de Pessoal de Nível Superior, CAPES - Brazil and MHC ALLS was supported by a doctoral grant awarded by Coordenação de Aperfeiçoamento de Pessoal de Nível Superior, CAPES.

The study was funded by "Conselho Nacional de Desenvolvimento Científico e Tecnológico" (CNPq Brazil), research grants 486177/2007-6 and 473572/ 2008-7.

\section{REFERENCES}

An WC, Li XM, 2009. Phosphate adsorption characteristics at the sediment-water interface and phosphorus fractions in Nansi Lake, China, and its main inflow rivers. Environ. Monit. Assess. 148:173-184.

Andersen FO, Jensen HS, 1992. Regeneration of inorganic phosphorus and nitrogen from decomposition of seston in freshwater sediment. Hydrobiologia 228:71-81.

Anthony JL, Lewis WM, 2012. Low boundary layer response and temperature dependence of nitrogen and phosphorus releases from oxic sediments of an oligotrophic lake. Aquat. Sci. 74:611-617.

Aspila KI, Agemian H, Chau ASY, 1976. A semi-automated method for the determination of inorganic, organic and total phosphate in sediments. Analyst 101:187-197.

Benelli S, Bartoli M, Zilius M, Vybernaite-Lubiene I, Ruginis T, Petkuviene J, Fano EA, 2018. Microphytobenthos and chironomid larvae attenuate nutrient recycling in shallowwater sediments. Freshwater Biol. 2:187-201.

Boers PCM, 1991. The influence of $\mathrm{pH}$ on phosphate release from lake sediments. Water Res. 25:309-311.

Burger DF, Hamilton DP, Pilditch CA, Gibbs MM, 2007. Benthic nutrient fluxes in a eutrophic, polymictic lake. Hydrobiologia 584:13-25.

Burnham KP, Anderson DR, 2002. Model selection and multimodel inference: a practical information-theoretic approach. Springer, New York: 488 pp.

Caliman A, Leal JJF, Esteves FA, Carneiro LS, Bozelli RL, Farjalla VF, 2007. Functional bioturbator diversity enhances benthic-pelagic processes and properties in experimental microcosms. J. N. Am. Benthol. Soc. 26:450-459.

Caraco NF, 1993. Disturbance of the phosphors cycle: a case of indirect effects of human activity. Trends Ecol. Evol. 8:51-54.

Chapra SC, Dove A, Warren GJ, 2012. Long-term trends of Great Lakes major ion chemistry. J. Great Lakes Res. 38: 550-560. doi:10.1016/j.jglr.2012.06.010

Chuai X, Zhou H, Chen X, Yang L, Zeng J, 2013. Effects of different primary producers (Cyanobacteria and Macrophyte) on the spatio-temporal distribution of phosphorus forms and concentrations in a lake. Pol. J. Environ. Stud. 22:1649-1659.

Clarke KR, Warwick RM, 2001. Change in marine communities: an approach to statistical analysis and interpretation. Plymouth Marine Laboratory: 176 pp.

Cummins KW, Merritt RW, Andrade PCN, 2005. The use of invertebrate functional groups to characterize ecosystem attributes in selected streams and rivers in south Brazil. Stud. Neotrop. Fauna Environ. 40:69-89.
Dong L, Yang Z, Liu X, 2011. Phosphorus fractions, sorption characteristics, and its release in the sediments of Baiyangdian Lake, China. Environ. Monit. Assess. 179:335-345.

Doremus C, Clesceri LS, 1982. Microbial metabolism in surface sediments and its role in the immobilization of phosphorus in oligotrophic lake sediments. Hydrobiologia 91:261-268.

Elser JJ, Hayakawa K, Urabe J, 2011. Nutrient limitation reduces food quality for zooplankton: Daphnia response to seston phosphorus enrichment. Ecology 82:898-903. doi: 10.1890/0012-9658(2001)082[0898:NLRFQF]2.0.CO;2

Engstrom DR, Almendinger JE, Wolin JA, 2009. Historical changes in sediment and phosphorus loading to the upper Mississippi River: mass-balance reconstructions from the sediments of Lake Pepin. J. Paleolimnol. 41:563-588.

Epler JH, 1995. Identification manual for the larvae Chironomidae (Diptera) of Florida Department of Environmental Protection, Division of Water Facilities, Tallahassee: $250 \mathrm{pp}$.

Fuentes EV, Petrucio MM, 2015.Water level decrease and increased water stability promotes phytoplankton growth in a mesotrophic subtropical lake. Mar. Freshw. Res. 66:711-718.

Gächter R, Meyer JS, 1993. The role of microorganisms in mobilization and fixation of phosphorus in sediments. Hydrobiologia 253:103-121.

Golterman HL, Clymo RS, Ohnstad MAM, 1978. Methods for physical and chemical analysis of freshwater. Blackwell Scientific, Hoboken: 213 pp.

Hennemann MC, Petrucio MM, 2011. Spatial and temporal dynamic of trophic relevant parameters in a subtropical coastal lagoon in Brazil. Environ. Monit. Assess. 181:347-361.

Hennemann MC, Simonassi JC, Petrucio MM, 2015. Paleolimnological record as an indication of incipient eutrophication in an oligotrophic subtropical coastal lake in Southern Brazil. Environ. Monit. Assess. 187:513. doi.org/10.1007/s10661-015-4726-9

Hou E, Chen C, McGroddy ME, Wen D, 2012. Nutrient limitation on ecosystem productivity and processes of mature and oldgrowth subtropical forests in China. PLoS One 7:e52071. https://doi.org/10.1371/journal.pone.0052071

Hupfer M, Lewandowski J, 2008. Oxygen controls the phosphorus release from lake sediments - a long-lasting paradigm in limnology. Int. Rev. Hydrobiol. 93:415-432. doi:10.1002/iroh.200711054

Jensen HS, Andersen F, 1992. Importance of temperature, nitrate, and $\mathrm{pH}$ for phosphate release from aerobic sediments of four shallow, eutrophic lakes. Limnol. Oceanogr. 37:577-589.

Kaiserli A, Voutsa D, Samara C, 2002. Phosphorus fractionation in lake sediments - Lakes Volvi and Koronia, N. Greece. Chemosphere 46:1147-1155.

Kangur M, Puusepp L, Buhvestova O, Haldna M, Kangur K, 2013. Spatio-temporal variability of surface sediment phosphorus fractions and water phosphorus concentration in Lake Peipsi (Estonia/Russia). Est. J. Earth Sci. 62:171-180.

Katsev S, Tsandev I, L'Heureux I, Rancourt DG, 2006. Factors controlling long-term phosphorus efflux from lake sediments: Exploratory reactive-transport modeling. Chem. Geol. 234:127-147.

Kinsman-Costello LE, Hamilton SK, O'Brien JM, Lennon JT, 2016. Phosphorus release from the drying and reflooding of diverse shallow sediments. Biogeochemistry 130:159.176. 
Kleeberg A, Dudel GE, 1997. Changes in extent of phosphorus release in a shallow lake (Lake Großer Miiggelsee; Germany, Berlin) due to climatic factors and load. Mar. Geol. 139:61-75.

Kleeberg A, Herzog C, 2014. Sediment microstructure and resuspension behavior depend on each other. Biogeochemistry 119:199-213.

Koroleff F, 1976. Determination of nutrients, p. 117-181. In: K. Grasshoff (ed.), Methods of seawater analysis. J. Wiley \& Sons, Chichester.

Lemes-Silva AL, Pires JR, Pagliosa PR, Petrucio MM, 2016. Distribution of aquatic macroinvertebrate assemblages in a subtropical coastal lake: response to environmental parameters. Fundam. Appl. Limnol. 188:113-127. DOI: $10.1127 / \mathrm{fal} / 2016 / 0786$

Lemes-Silva AL, Petrucio MM, 2018. Relationships between aquatic invertebrate communities, water-level fluctuations and different habitats in a subtropical lake. Environ. Monit. Assess. 190:548.

Lijklema L, 1993. Considerations in modeling the sedimentwater exchange of phosphorus. Hydrobiologia 253:219-231.

Lisboa LK, Lemes-Silva AL, Petrucio MM, 2011. Aquatic invertebrate's distribution in a freshwater coastal lagoon of southern Brazil in relation to water and sediment characteristics. Acta Limnol. Brasil 23:1-9.

Liu E, Shen J, Yang X, Zhang E, 2012. Spatial distribution and human contamination quantification of trace metals and phosphorus in the sediments of Chaohu Lake, a eutrophic shallow lake, China. Environ. Monit. Assess. 184:2105-2118.

Lorenzen CJ, 1967. Determination of chlorophyll and phaeopigments: spectrometric equations. Limnol. Oceanogr. 12:343-346.

Mackereth FJH, Heron J, Talling JF, 1978. Water analysis: Some revised methods for limnologists. Freshwater Biological Association, Cumbria: 120 pp.

Malmqvist B, Rundle S, 2002. Threats to running water ecosystems of the word. Environ. Conserv. 29:134-153.

Merritt RW, Cummins KW, 1984. An introduction to the aquatic insects of North America. Kendall/Hunt, Dubuque: 722 pp.

Montigny C, Prairie YT, 1993. The relative importance of biological and chemical processes in the release of phosphorus from a highly organic sediment. Hydrobiologia 253:141-150.

Mortimer CH, 1941. The exchange of dissolved substances between mud and water in lakes. J. Ecol. 29:280-329.

Pech D, Ardisson PL, Hernández-Guevara NA, 2007. Benthic community response to habitat variation: A case of study from a natural protected area, the Celestun coastal lagoon. Cont. Shelf Res. 27:2523-2533.

Pieczynska E, 1993. Detritus and nutrient dynamics in the shore zone of lakes: a review. Hydrobiologia 251:49-58.
Søndergaard M, Jensen PJ, Jeppesen E, 2001. Retention and internal loading of phosphorus in shallow, eutrophic lakes. Sci. World. 1:427-442.

Søndergaard M, Jensen PJ, Jeppesen E, 2003. Role of sediment and internal loading of phosphorus in shallow lakes. Hydrobiologia 509:135-145.

Spears BM, Carvalho L, Perkins R, Kirika A, Paterson DM, 2006. Spatial and historical variation in sediment phosphorus fractions and mobility in a large shallow lake. Water Res. 40:383-391.

Strickland JDH, Parsons TR, 1960. A manual of seawater analysis. B. Fish. Res. Board Can. 125:1-185.

Suguio K, 1973. [Introdução a sedimentologia].[Book in Portuguese]. Edgar Blucher Ltda, São Paulo: 317 pp.

Tomanova S, Usseglio-Polatera P, 2007. Patterns of benthic community traits in neotropical streams: relationship to mesoscale spatial variability. Fundam. Appl. Limnol. Arch. Hydrobiol. 170:155-167.

Tonetta D, Staehr PA, Petrucio MM, 2017. Changes in CO2 dynamics related to rainfall and water level variations in a subtropical lake. Hydrobiologia 794:109-123. Doi 10.1007/s10750-017-3085-7.

Torres IC, Turner BL, Reddy KR, 2014. The Chemical Nature of Phosphorus in Subtropical Lake Sediments. Aquat. Geochem. 20:437-457.

Trivinho-Strixino S, Strixino G, 1995. [Larvas de Chironomidae (Diptera) do Estado de São Paulo. Guia de identificação e diagnose dos gêneros].[Book in Portuguese]. PPGERN/UFSCAR, São Carlos, 229 pp.

Valderrama JC, 1981. The simultaneous analysis of total nitrogen and phosphorous in natural waters. Mar. Chem. 10:109-122.

Wallace JB, Webster JR, 1996. The role of macroinvertebrates in stream ecosystem function. Annu. Rev. Entomol. 41:115-39.

Wazbinzki KE, Quinlan R, 2013. Midge (Chironomidae, Chaoboridae, Ceratopogonidae) assemblages and their relationship with biological and physicochemical variables in shallow, polymictic lakes. Freshwater Biol. 58:2464-2480.

Wetzel RG, 2001. Limnology: Lake and river ecosystems. San Diego Academic Press, San Diego: 1006 pp.

Wu Y, Wen Y, Zhou J, Wu Y, 2014. Phosphorus release from lake sediments: Effects of $\mathrm{pH}$, temperature and dissolved oxygen. KSCE J. Civil Eng. 18:323-329.

Zhang L, Liao Q, Gu X, He W, Zhang Z, Fan C, 2014. Oxygen and phosphorus dynamics in freshwater sediment after the deposition of flocculated cyanobacteria and the role of tubificid worms. J. Hazard Mater. 266:1-9.

Zhu Y, Zhang R, Wu F, Qu X, Xie F, Fu Z, 2013. Phosphorus fractions and bioavailability in relation to particle size characteristics in sediments from Lake Hongfeng, Southwest China. Environ. Earth Sci. 68:1041-1052. 